Article

\title{
Disposable Stainless-Steel Wire-Based Electrochemical Microsensor for In Vivo Continuous Monitoring of Hydrogen Peroxide in Vein of Tomato Leaf
}

\author{
Doudou Huo ${ }^{1, \dagger}$, Daodong Li ${ }^{1, \dagger}$, Songzhi Xu ${ }^{1, \dagger}$, Yujie Tang ${ }^{1}$, Xueqian Xie ${ }^{1}$, Dayong Li ${ }^{2}$, Fengming Song ${ }^{2}$, \\ Yali Zhang ${ }^{3}$, Aixue $\mathrm{Li}^{4}$ and Lijun Sun ${ }^{1, *}$
}

1 School of Life Sciences, Nantong University, 9 Seyuan Road, Nantong 226019, China; 1909310002@stmail.ntu.edu.cn (D.H.); 2008310015@stmail.ntu.edu.cn (D.L.); xusongzhi@ntu.edu.cn (S.X.); 2009110168@stmail.ntu.edu.cn (Y.T.); 2009110180@stmail.ntu.edu.cn (X.X.)

2 National Key Laboratory for Rice Biology, Institute of Biotechnology, Zhejiang University, Hangzhou 310029, China; dyli@zju.edu.cn (D.L.); fmsong@zju.edu.cn (F.S.)

3 School of Medicine, Nantong University, Qixiu Road 19, Nantong 226001, China; zyl031912@ntu.edu.cn

4 Beijing Research Center of Intelligent Equipment for Agriculture, Beijing Academy of Agriculture and Forestry Sciences, Beijing 100097, China; liax@nercita.org.cn

* Correspondence: slj.1226@ntu.edu.cn

+ These authors contributed equally to this work.

check for updates

Citation: Huo, D.; Li, D.; Xu, S.; Tang, Y.; Xie, X.; Li, D.; Song, F.; Zhang, Y.;

Li, A.; Sun, L. Disposable Stainless-Steel Wire-Based Electrochemical Microsensor for In Vivo Continuous Monitoring of Hydrogen Peroxide in Vein of Tomato Leaf. Biosensors 2022, 12, 35. https://doi.org/10.3390/ bios12010035

Received: 8 December 2021

Accepted: 8 January 2022

Published: 12 January 2022

Publisher's Note: MDPI stays neutral with regard to jurisdictional claims in published maps and institutional affiliations.

Copyright: (C) 2022 by the authors. Licensee MDPI, Basel, Switzerland. This article is an open access article distributed under the terms and conditions of the Creative Commons Attribution (CC BY) license (https:// creativecommons.org/licenses/by/ $4.0 /)$.

\begin{abstract}
As one of the pivotal signal molecules, hydrogen peroxide $\left(\mathrm{H}_{2} \mathrm{O}_{2}\right)$ has been demonstrated to play important roles in many physiological processes of plants. Continuous monitoring of $\mathrm{H}_{2} \mathrm{O}_{2}$ in vivo could help understand its regulation mechanism more clearly. In this study, a disposable electrochemical microsensor for $\mathrm{H}_{2} \mathrm{O}_{2}$ was developed. This microsensor consists of three parts: low-cost stainless-steel wire with a diameter of $0.1 \mathrm{~mm}$ modified by gold nanoparticles (disposable working electrode), an untreated platinum wire with a diameter of $0.1 \mathrm{~mm}$ (counter electrode), and an $\mathrm{Ag} / \mathrm{AgCl}$ wire with a diameter of $0.1 \mathrm{~mm}$ (reference electrode), respectively. The microsensor could detect $\mathrm{H}_{2} \mathrm{O}_{2}$ in levels from 10 to $1000 \mu \mathrm{M}$ and exhibited excellent selectivity. On this basis, the dynamic change in $\mathrm{H}_{2} \mathrm{O}_{2}$ in the vein of tomato leaf under high salinity was continuously monitored in vivo. The results showed that the production of $\mathrm{H}_{2} \mathrm{O}_{2}$ could be induced by high salinity within two hours. This study suggests that the disposable electrochemical microsensor not only suits continuously detecting $\mathrm{H}_{2} \mathrm{O}_{2}$ in microscopic plant tissue in vivo but also reduces the damage to plants. Overall, our strategy will help to pave the foundation for further investigation of the generation, transportation, and elimination mechanism of $\mathrm{H}_{2} \mathrm{O}_{2}$ in plants.
\end{abstract}

Keywords: plants; hydrogen peroxide; disposable stainless-steel wire; electrochemical microsensor; in vivo and continuous electrochemical monitoring

\section{Introduction}

Hydrogen peroxide $\left(\mathrm{H}_{2} \mathrm{O}_{2}\right)$, a simple molecular compound discovered by Louis Jacques Denard a hundred years ago, is one of the crucial members of the reactive oxygen species (ROS) [1,2]. Compared to the other ROS members such as ${ }^{1} \mathrm{O}_{2}, \mathrm{O}_{2}$, and $\mathrm{OH}$, $\mathrm{H}_{2} \mathrm{O}_{2}$ is more stable. $\mathrm{H}_{2} \mathrm{O}_{2}$ is generally produced in various cellular components such as chloroplast, peroxisomes, and mitochondria, where many metabolic pathways occur in plants [2-6]. The levels of $\mathrm{H}_{2} \mathrm{O}_{2}$ in the fresh leaf extraction were significantly different in different plants under normal growth conditions [7]. For example, the concentrations of $\mathrm{H}_{2} \mathrm{O}_{2}$ ranged from $0.15 \mu \mathrm{mol} \cdot(\mathrm{g} \cdot \mathrm{FW})^{-1}$ in tobacco leaves to $6 \mu \mathrm{mol} \cdot(\mathrm{g} \cdot \mathrm{FW})^{-1}$ in marigold leaves under normal conditions [8,9]. Tewari et al. reported that the localization of $\mathrm{H}_{2} \mathrm{O}_{2}$ in different regions of maize leaf exhibited an increasing pattern from the base to the leaf tip [10]. In general, there is a balance between the production and elimination of $\mathrm{H}_{2} \mathrm{O}_{2}$. However, this balance can be broken by stresses or mechanical wounding [11]. $\mathrm{H}_{2} \mathrm{O}_{2}$ is also 
a core component of plant signaling networks to regulate plant growth and development, as well as responding to various stresses [1,12]. It has been reported that abscisic acid can induce the production of $\mathrm{H}_{2} \mathrm{O}_{2}$, further inactive $\mathrm{Ca}^{2+}$ channels, which are one crucial step for ABA-induced stomatal closing to improve drought resistance [13]. Salicylic acid can elevate the amount of $\mathrm{H}_{2} \mathrm{O}_{2}$ to induce the expression of defense genes to increase the resistance to the pathogen $[14,15]$. The concentration of $\mathrm{H}_{2} \mathrm{O}_{2}$ can be enhanced when the catalase activity of SABP (salicylic acid bind protein) was inhibited [14,15].

Although studies about the roles of $\mathrm{H}_{2} \mathrm{O}_{2}$ in the signal transduction, especially in crosstalk with the plant hormones in the stresses have made great progress [1,11], direct experimental evidence is lacking regarding the sites, initiation time, and transportation of $\mathrm{H}_{2} \mathrm{O}_{2}$. Obtaining this evidence is limited on how to determine the concentration distribution and dynamic change in $\mathrm{H}_{2} \mathrm{O}_{2}$ in plants. Currently, titration, spectroscopy colorimetry, fluorescence, chemiluminescence, and chromatography are widely used in the detection of the $\mathrm{H}_{2} \mathrm{O}_{2}$ concentration [16-24]. The success of these methods is limited by the long time required for sample preparation, especially for separating or grinding plant samples before determination. The complicated and time-consuming pre-treatment of plant samples leads to a loss or change in $\mathrm{H}_{2} \mathrm{O}_{2}$, which makes it difficult to obtain the concentration of $\mathrm{H}_{2} \mathrm{O}_{2}$ in situ and in realtime.

The electrochemical method provides a convenient way for in vivo or real-time detection of IAA, SA, glucose, and sucrose in plants because of its easy operation, high sensitivity, and selectivity for detecting and quantifying [25-27]. For detecting the $\mathrm{H}_{2} \mathrm{O}_{2}$ in plants in situ, a few studies such as paper-based electroanalytical devices or microelectrode sensors have been described [28-31]. In our previous study, a paper-based electroanalytical device provided a rapid and direct electrochemical determination of $\mathrm{H}_{2} \mathrm{O}_{2}$ in tomato leaves inoculated with Botrytis cinerea, however, there were still some problems [31]. For example, there was great damage to the plants during the detection of $\mathrm{H}_{2} \mathrm{O}_{2}$. The continuous monitoring of $\mathrm{H}_{2} \mathrm{O}_{2}$ in plants could also not be realized in this system. Single-walled carbon nanotubes and hemoglobin-modified carbon fiber ultramicroelectrodes were used to detect the $\mathrm{H}_{2} \mathrm{O}_{2}$ in vivo on aloe under salinity stress [30]. A platinum disc microelectrode sensor was employed to monitor the $\mathrm{H}_{2} \mathrm{O}_{2}$ in Agavetequilana leaves after inoculation with endophytic bacteria [29]. Although these microelectrode sensors could be used to detect $\mathrm{H}_{2} \mathrm{O}_{2}$ [28-30], microelectrode sensors that can be prepared simply and are low-cost and disposable are still needed. Recently, stainless-steel materials have been used as electrodes to detect dopamine, levodopa, uric acid, and heavy metals due to their excellent properties such as good electrical conductivity, lowcost, high mechanical strength, environmentally friendly, and commercial availability [32-35]. More importantly, the diameter of stainless-steel wires can be reduced to the micrometer level, which is very suited to fabricate the microelectrode sensors. For example, $0.127 \mathrm{~mm}$ stainless-steel wires were used as the electrodes in the biobotic [36].

In this study, a disposable microsensor based on $0.1 \mathrm{~mm}$ stainless-steel wire was constructed for electrochemical detection of $\mathrm{H}_{2} \mathrm{O}_{2}$. This microsensor showed excellent electrochemical detection performance. The dynamic change in $\mathrm{H}_{2} \mathrm{O}_{2}$ in the vein of tomato leaf under high salinity was continuously monitored in vivo. This study suggested that the disposable electrochemical microsensor is not only suitable for continuously detecting $\mathrm{H}_{2} \mathrm{O}_{2}$ in microscopic plant tissue in vivo but can also reduce the damage to plants, which will help pave the foundation for further investigation of the generation, transportation, and elimination mechanisms of $\mathrm{H}_{2} \mathrm{O}_{2}$ in plants. 


\section{Materials and Methods}

\subsection{Chemicals and Materials}

Hydrogen tetrachloroaurate (III) trihydrate $\left(\mathrm{HAuCl}_{4} \cdot 3 \mathrm{H}_{2} \mathrm{O}\right)$ was obtained from Sigma (St. Louis, MO, USA). The 304 stainless-steel wire (SS, $\mathrm{d}=0.1 \mathrm{~mm})$, platinum wire $(\mathrm{Pt}$, $\mathrm{d}=0.1 \mathrm{~mm})$, and silver wire $(\mathrm{Ag}, \mathrm{d}=0.1 \mathrm{~mm})$ were obtained from Alfa Aesar Chemical Co., Ltd. (Shanghai, China). The sample capillary was obtained from Shanghai Dongming Glass instrument Co., Ltd. (Shanghai, China). Double-conductor copper foil tape was obtained by Shenzhen Wangxing Tape Co., Ltd. (Shenzhen, China). The 3M superglue was obtained from 3M China Co., Ltd. (Shenzhen, China). The tomato seeds of one generation hybrid, Shanghai906, were obtained from Lintong Changfeng Vegetable Breeding Farm (Xi'an, China). $\mathrm{H}_{2} \mathrm{O}_{2}$ was purchased from Shanghai Zhanyun Chemical Co., Ltd. (Shanghai, China). All the other chemical reagents were analytical grade. Double distilled water was used in all experiments.

\subsection{Material Preparation}

$\mathrm{HAuCl}_{4} \cdot 3 \mathrm{H}_{2} \mathrm{O}(10 \mathrm{~g} / \mathrm{L})$ was distilled by the double distilled water to prepare $0.5 \mathrm{mmol} / \mathrm{L} \mathrm{HAuCl} \mathrm{H}_{4} \cdot 3 \mathrm{H}_{2} \mathrm{O}$ for electroplating. Thirty percent of $\mathrm{H}_{2} \mathrm{O}_{2}$ was diluted to different concentrations by $0.2 \mathrm{M}$ phosphate-buffered solution (PBS) with $\mathrm{pH} 7.0$ for detection. Tomato plants were grown in a mixture of perlite: plant ash: vermiculite (1:2:6) in a growth room at $22{ }^{\circ} \mathrm{C}$. The lighting regime for the tomato plants was $16 \mathrm{~h}$ of light $/ 8 \mathrm{~h}$ dark at a total light intensity of around $540 \mu \mathrm{mol} / \mathrm{m}^{2} / \mathrm{S}$. For analysis of the production and transportation of $\mathrm{H}_{2} \mathrm{O}_{2}$ in the vein of tomato leaf response to high salinity stress, six-week-old tomato was treated with $0.4 \mathrm{M} \mathrm{NaCl}$ solution. As shown in Figure S1, the lateral stem of tomato was cut and the end of the stem was wrapped with cotton soaked in water (control) or $0.4 \mathrm{M} \mathrm{NaCl}$ solution (high salinity stress).

\subsection{The Preparation of SS Wire-Based Electrochemical Microsensor}

The SS wire, Pt wire, and silver wire were cut into $50 \mathrm{~mm}$ segments and washed with ethanol, water under ultrasonic for $10 \mathrm{~min}$, and dried at room temperature, respectively. The capillaries $(\mathrm{d}=0.3 \mathrm{~mm})$ were cut into $35 \mathrm{~mm}$ segments and an SS wire was placed into the capillary (Scheme 1A). One end of the SS wire was exposed to a length of $2 \mathrm{~mm}$ for sample testing, and the other end of the SS wire was exposed to a length of $13 \mathrm{~mm}$ for linking to the electrochemical workstation. The SS wire was fixed in the capillary by the 3M super glue. Finally, copper conductive tape was applied to the end of the $13 \mathrm{~mm}$ SS wire (Scheme 1B). Then, electrodeposition of nano-Au on the bare SS was carried out in a $0.5 \mathrm{mmol} / \mathrm{L} \mathrm{HAuCl}_{4}$ solution under the potential from -0.8 to $0 \mathrm{~V}$ by cyclic voltammetry (CV) (Scheme 1C). The modified SS wire was used as a working electrode (Au/SS electrode). The unmodified $\mathrm{Pt}$ wire (counter electrode) was fixed in the capillary in the same way as the SS wire. For the reference electrode, the $0.1 \mathrm{~mm}$ silver wire was fixed in the capillary in the same way as the Pt electrode. Then, the fixed-silver wire was soaked in 84 disinfectant (the main composition is $\mathrm{NaClO}$ ) for $30 \mathrm{~min}$ to generate a silver/silver chloride electrode (Ag/AgCl). 


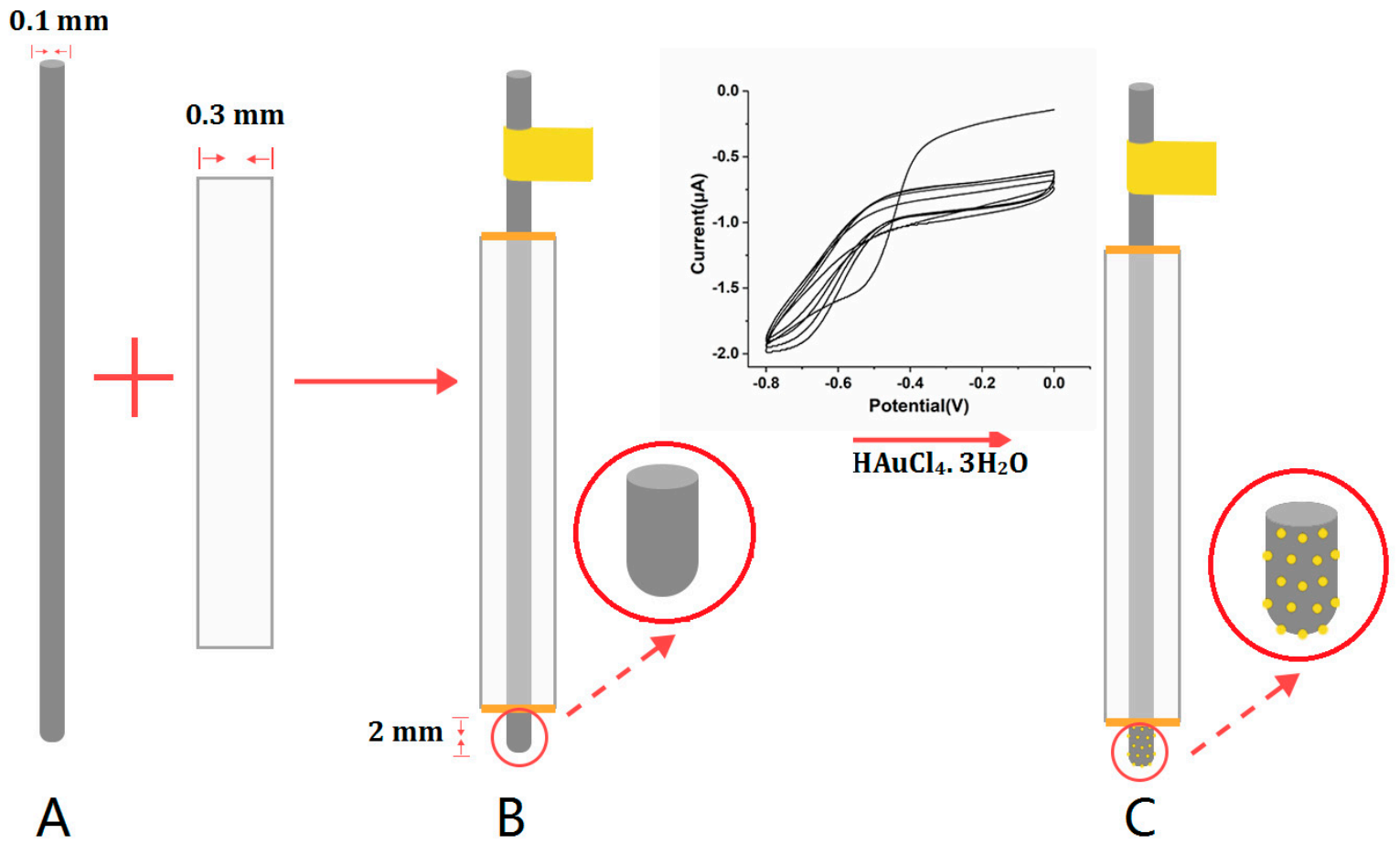

Scheme 1. The preparation process of disposable stainless-steel (SS) wire-based electrochemical microsensor system: (A) bare SS electrode; (B) fixed-bare SS electrode in capillary; (C) the nano-Au modified bare SS electrode (Au/SS).

\subsection{Electrochemical Measurements}

All electrochemical experiments were carried out on a CHI 1240C electrochemical station. The electrocatalytic behaviors of the electrochemical detection system toward $\mathrm{H}_{2} \mathrm{O}_{2}$ were investigated by $\mathrm{CV}$ with the potential from -1.0 to $0.6 \mathrm{~V} . \mathrm{H}_{2} \mathrm{O}_{2}$ was detected by an amperometric i-t curve with an initial potential of $-0.6 \mathrm{~V}$, sample interval of $0.1 \mathrm{~s}$, running time of $1500 \mathrm{~s}$, quiet time of $0 \mathrm{~s}$, scales during a run of 1 on the SS wire-based electrochemical microsensor.

\section{5. qRT-PCR Analysis of Gene Expression}

In order to evaluate the level of $\mathrm{H}_{2} \mathrm{O}_{2}$ in the vein of tomato leaves, the expression of $S L R b o h A$ and $S L R b o h B$ was analyzed. Total RNA was extracted from the vein of tomato leaves $(0.20 \mathrm{~g}$ fresh weight) with TRIzol (Invitrogen, Shanghai, China) and then treated with RNase-free DNase (TaKaRa, Dalian, China). First-strand cDNAs were synthesized by AMV reserve transcriptase (TaKaRa, Dalian, China) as instructed. The obtained cDNA was used for gene expression analysis with qRT-PCR. Each qPCR reaction contained $0.1 \mu \mathrm{g}$ cDNA, 7.5 pmol of each gene-specific primer (Table S1), and $12.5 \mu \mathrm{L} \times 2$ SYBR premix Ex TaqTM (TaKaRa, Dalian, China) in a final volume of $25 \mu \mathrm{L}$. The qRT-PCR was performed in a Roche $L C 480$ real-time quantitative polymerase chain reaction detection system. The relative gene expression levels were calculated using the $2^{-\Delta \Delta C T}$ method as described [37]. Three independent biological replicates were analyzed.

\section{Results and Discussion}

\subsection{Characterization of theModified Electrodes}

The surface characterization of the electrode was observed using a scanning electron microscope (ZEISSSEM300, Oberkochen, Germany). As shown in Figure 1, the surface of the bare SS wire electrode with a diameter of $0.1 \mathrm{~mm}$ is smooth (Figure 1A).The electrodeposition methods were used to deposit gold nanoparticles on the bare SS wire electrode. Compared to the bare SS electrode, the $5 \sim 15 \mathrm{~nm}$ gold nanoparticles homogeneously dis- 
tributed throughout the surface of the bare SS wire electrode (Figure 1C). The element composition of the modified electrodes was also characterized by an energy dispersive spectrometer (Oxford Instruments, UK). As shown in Figure 1B, the main element of bare SS wire electrode was $\mathrm{Fe}$, above $60.9 \%$. After electrodepositing of Au, the elemental composition of Fe decreased to $52.8 \%$, while the $\mathrm{Au}$ increased from $0 \%$ to $7.2 \%$ (Figure 1D). All of these results suggested the gold nanoparticles were electroplated on the bare SS wire electrode.

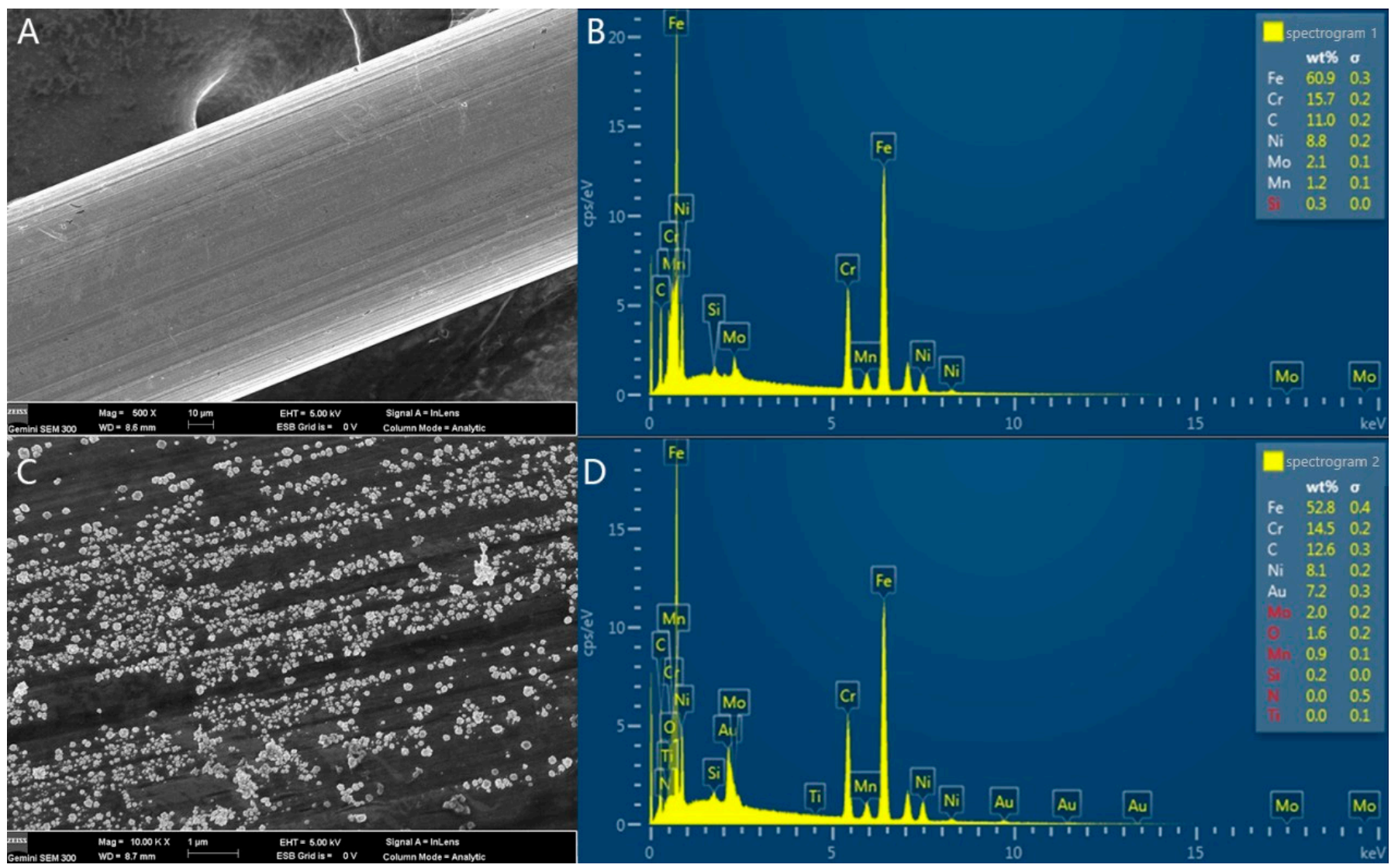

Figure 1. The SEM (A,C) and EDS (B,D) spectrum analysis of bare SS and Au/SS electrode.

\subsection{The Electrochemical Performance of the Au/SSWire-Based Electrochemical Microsensor}

The electrocatalytic behavior of the Au/SS wire-based electrochemical microsensortoward $\mathrm{H}_{2} \mathrm{O}_{2}$ reduction was investigated using $\mathrm{CV}$. There was only one reduction peak of $\mathrm{CV}$ curves at around $-0.7 \mathrm{~V}$ on the bare SS wire electrode in the presence of $100 \mu \mathrm{M}$ $\mathrm{H}_{2} \mathrm{O}_{2}$ (Figure 2A).Compared to the bare SS wire electrode, the CV curves changed with an obvious reduction peak at around $-0.7 \mathrm{~V}$ and $-0.2 \mathrm{~V}$ on the $\mathrm{Au} / \mathrm{SS}$ electrode (Figure 2A). Such results showed that $\mathrm{Au}$ nanoparticles possess exceptional electrical conductivity and electrocatalytic activity, which could improve the electrochemical response of $\mathrm{H}_{2} \mathrm{O}_{2}$. Moreover, with the addition of $\mathrm{H}_{2} \mathrm{O}_{2}$ from concentrations of 0 to $1500 \mu \mathrm{M}$, the reduction current of $\mathrm{H}_{2} \mathrm{O}_{2}$ at around $-0.7 \mathrm{~V}$ was enhanced gradually, while there was no obvious increase at $-0.2 \mathrm{~V}$, which suggested that the electrocatalytic reaction of $\mathrm{H}_{2} \mathrm{O}_{2}$ mainly occurs at $-0.7 \mathrm{~V}$ (Figure 2B). Figure 2C shows the curves of the SS wire-based electrochemical microsensor system with the increase in scanning rates from 10 to $300 \mathrm{mV} / \mathrm{s}$. The results showed that the reduction peak current of $100 \mu \mathrm{M} \mathrm{H}_{2} \mathrm{O}_{2}$ decreased linearly with the increase in the scan rates, which suggested that the redox process of the modified electrode surface is an adsorption-controlled process with an irreversible electroreduction of $\mathrm{H}_{2} \mathrm{O}_{2}$. In addition, the reduction peak potential of $\mathrm{H}_{2} \mathrm{O}_{2}$ at around $-0.7 \mathrm{~V}$ gradually moves toward the negative direction with the increase in scanning rates, which is possibly caused by the torpid electron transfer kinetics. 

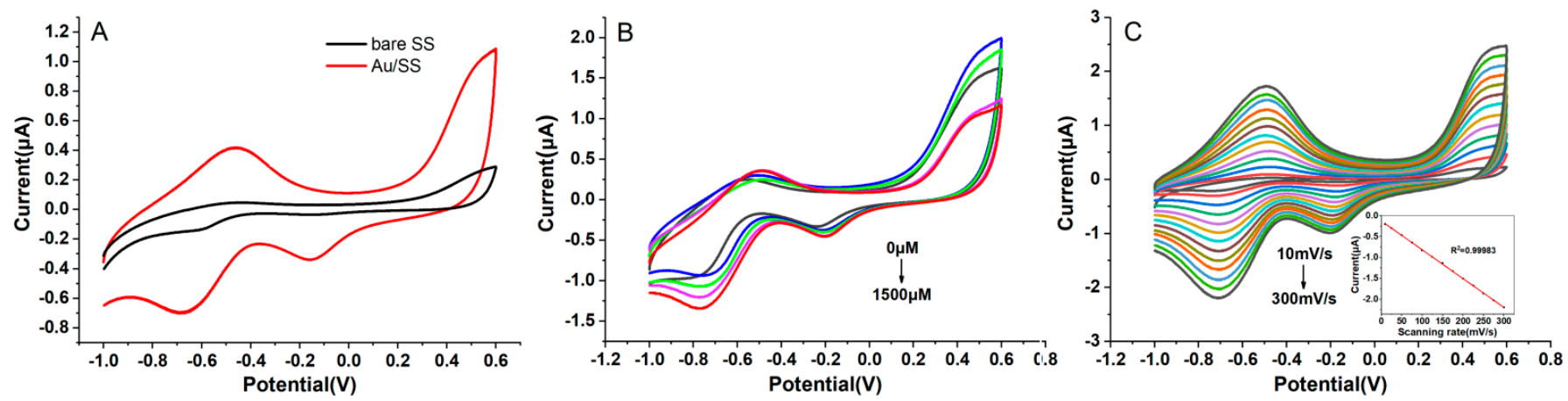

Figure 2. (A) CV curves of bare SS, and Au/SS wire-based electrochemical microsensor in the presence of $100 \mu \mathrm{M} \mathrm{H}_{2} \mathrm{O}_{2}$ in $0.2 \mathrm{M}$ PBS with $\mathrm{pH} 7$ solution at the scanning rate of $100 \mathrm{mV} \cdot \mathrm{s}^{-1}$. (B) CV curves of $\mathrm{Au} / \mathrm{SS}$ wire-based electrochemical microsensor in the absence of $\mathrm{H}_{2} \mathrm{O}_{2}$ and the presence of different concentrations of $\mathrm{H}_{2} \mathrm{O}_{2}$ in $0.2 \mathrm{M}$ PBS with $\mathrm{pH} 7$ solution at the scanning rate of $100 \mathrm{mV} \cdot \mathrm{s}^{-1}$. The concentrations of $\mathrm{H}_{2} \mathrm{O}_{2}$ were $0 \mu \mathrm{M}$ (control, black line), $100 \mu \mathrm{M}$ (blue line), $500 \mu \mathrm{M}$ (green line), $1000 \mu \mathrm{M}$ (pink line), and $1500 \mu \mathrm{M}$ (red line), respectively. (C) CV curves of SS wire-based electrochemical microsensor at different scanning rates in $100 \mu \mathrm{M} \mathrm{H}_{2} \mathrm{O}_{2}$ solution. The scanning rate ranges from 10 to $300 \mathrm{mV} \cdot \mathrm{s}^{-1}$.

\subsection{Amperometric Detection of $\mathrm{H}_{2} \mathrm{O}_{2}$ with the Au/SS Wire-Based Electrochemical Microsensor}

Considering the great influence of potential on the sensitivity, the amperometric $\mathrm{i}-\mathrm{t}$ method was used to estimate the influence of the applied potential on the Au/SS wire-based electrochemical microsensor. As shown in Figure 3A, the influence of different applied potentials $(-0.9,-0.8,-0.7,-0.6,-0.5$, and $-0.4 \mathrm{~V})$ on the amperometric response of the $\mathrm{Au} / \mathrm{SS}$ wire-based electrochemical microsensor system was investigated by continuously adding $100 \mu \mathrm{M} \mathrm{H}_{2} \mathrm{O}_{2}$ into $0.2 \mathrm{M} \mathrm{PBS}$ solution. The signal-to-noise ratio (a ratio of the current response signal to background noise, $\mathrm{S} / \mathrm{N}$ ratio) can reflect the sensitivity of the detection system. It was observed that the $S / N$ ratio increased and reached a maximum value at $-0.6 \mathrm{~V}$, then gradually decreased (Figure 3B). Therefore, an applied potential of $-0.6 \mathrm{~V}$ for the amperometric i-t method was selected in the following experiments. Whether the untreated stainless-steel wires could be used as reference electrodes and counter electrodes was studied. Compared to the present electrode system, the untreated stainless-steel wire could not be used as reference electrode and counter electrodes due to the big background noise (Figure S2). The influence of working electrodes fabrication with the different steel wire diameters $(0.1,0.05$, and $0.01 \mathrm{~mm})$ on the electrochemical detection of $\mathrm{H}_{2} \mathrm{O}_{2}$ was also studied. The results showed that the highest current response was the steel wire with a diameter of $0.1 \mathrm{~mm}$ (Figure S3).

The typical amperometric (i-t) curves of the Au/SS wire-based electrochemical microsensor were recorded by the successive addition of $\mathrm{H}_{2} \mathrm{O}_{2}$ with different concentrations into 0.2 M PBS solution at an applied potential of $-0.6 \mathrm{~V}$ (Figure 4 ). The response of the $\mathrm{H}_{2} \mathrm{O}_{2}$ on the bare SS and Au/SS wire electrodes was also compared. As shown in Figure 4A, the response of $\mathrm{H}_{2} \mathrm{O}_{2}$ on the Au/SS wire electrode was higher than the SS wire, which showed that $\mathrm{Au}$ nanoparticles modified SS wire could improve electrochemical detection of $\mathrm{H}_{2} \mathrm{O}_{2}$. The current response value increased with the increase in $\mathrm{H}_{2} \mathrm{O}_{2}$ concentration (Figure 4B). There was a good linear relationship between the current variation of $\mathrm{H}_{2} \mathrm{O}_{2}$ and the concentration of $\mathrm{H}_{2} \mathrm{O}_{2}$ in the range of $10 \mu \mathrm{M}$ to $1000 \mu \mathrm{M}$ (Figure $4 \mathrm{C}$ ). After adding $500 \mu \mathrm{M} \mathrm{H}_{2} \mathrm{O}_{2}$ in stirring PBS solution, the reduction current of the Au/SS wire-based electrochemical microsensor system showed a significant increase and obtained the maximum steady-state current within $1.6 \mathrm{~s}$ (Figure 5A). The possible interference from the plant molecules in plant fluids for the determination of $\mathrm{H}_{2} \mathrm{O}_{2}$ in plants was also investigated. Figure $5 \mathrm{~B}$ shows that no significant interferences were observed for the determination of $\mathrm{H}_{2} \mathrm{O}_{2}$ in the presence of salicylic acid (SA), indole-3-acetic acid (IAA), methyl jasmonate (MeJA), abscisic acid (ABA), ascorbic acid (AA), malic acid $\left(\mathrm{H}_{2} \mathrm{MA}\right)$, succinic acid, and citric 
acid (CA) with $100 \mu \mathrm{M}$, respectively. These results suggested that the Au/SS wire-based electrochemical microsensor system can be used for the determination of $\mathrm{H}_{2} \mathrm{O}_{2}$ in real samples. The reproducibility of the Au/SS wire-based electrochemical microsensor was evaluated from the response on $100 \mu \mathrm{M} \mathrm{H}_{2} \mathrm{O}_{2}$ using six working electrodes. The relative standard deviation was about $5.8 \%$ and indicated a good reproducibility of the Au/SS wirebased electrochemical microsensor. The limit of detection (LOD) was 3.97 $\mu \mathrm{M}$. The stability of the Au/SS wire-based electrochemical microsensor was also tested. The results showed that the Au/SS wire-based electrochemical microsensor could be used at least seven times and maintained stability for at least seven days (Figure S4). These results suggested that the $\mathrm{Au} / \mathrm{SS}$ wire-based electrochemical microsensor system can be used for the determination of $\mathrm{H}_{2} \mathrm{O}_{2}$ in real samples. Compared with previous reports [28-31,38-40], the disposable SS wire-based electrochemical microsensor was superior regarding the low cost (about USD 0.02, suitable for mass production), simple preparation (less than 20 min to prepare this system), good analytical performance, and in vivo and continuous electrochemical monitoring of $\mathrm{H}_{2} \mathrm{O}_{2}$ in plants (Table S2).
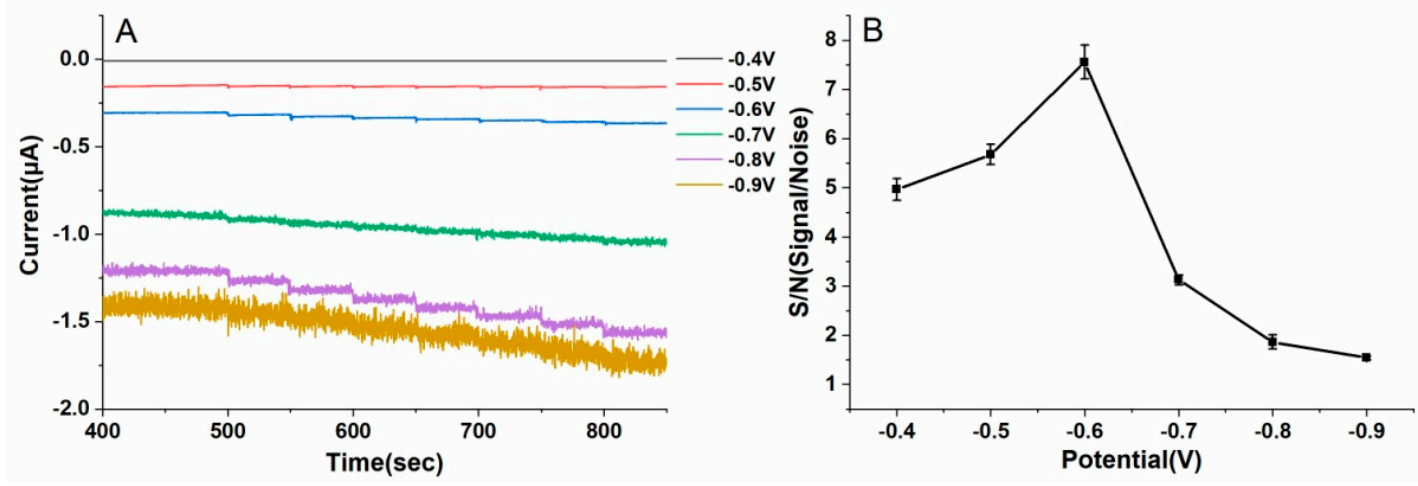

Figure 3. (A) The amperometric response of Au/SS wire-based electrochemical microsensor to continuous additions $10 \mu \mathrm{LH}_{2} \mathrm{O}_{2}$ with concentration $100 \mathrm{mMin} 10 \mathrm{~mL}$ solution with $0.2 \mathrm{M} \mathrm{PBS}$ (pH 7) at different application potentials. (B) The relationship between $\mathrm{S} / \mathrm{N}$ ratio and applied potential $(n=7)$.
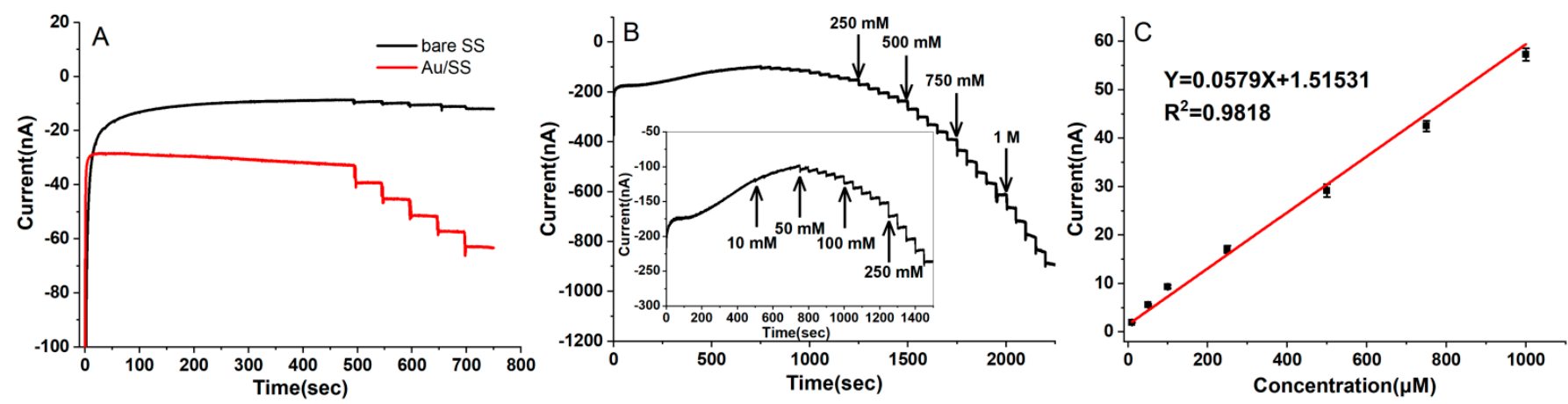

Figure 4. (A) Amperometric response of the bare SS and Au/SS wire-based electrochemical microsensor to successive additions of $10 \mu \mathrm{L} \mathrm{H}_{2} \mathrm{O}_{2}$ with concentration $100 \mathrm{mM}$ in $10 \mathrm{~mL}$ solution with $0.2 \mathrm{M}$ PBS ( $\mathrm{pH} 7$ ) at $-0.6 \mathrm{~V}$ application potential. (B) Amperometric response of the Au/SS wire-based electrochemical microsensor to successive additions of $10 \mu \mathrm{L} \mathrm{H}_{2} \mathrm{O}_{2}$ with concentration $10 \mathrm{mM}, 50 \mathrm{mM}$, $100 \mathrm{mM}, 250 \mathrm{mM}, 500 \mathrm{mM}, 750 \mathrm{mM}$, and $1000 \mathrm{mM}$, respectively, in $10 \mathrm{~mL}$ solution with $0.2 \mathrm{M}$ PBS $(\mathrm{pH} 7)$ at $-0.6 \mathrm{~V}$ application potential. $(\mathrm{C})$ Linear relation between the amperometric response and $\mathrm{H}_{2} \mathrm{O}_{2}$ concentration ranging from $10 \mu \mathrm{M}$ to $1000 \mu \mathrm{M}(n=5)$. 

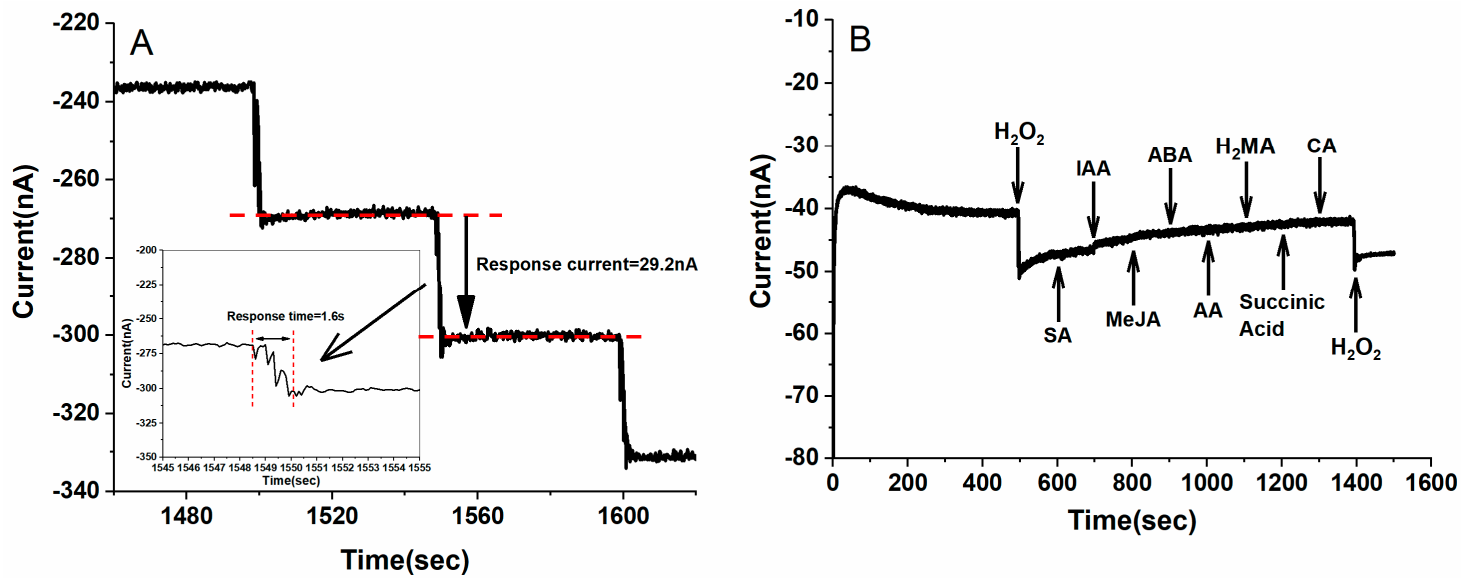

Figure 5. (A) Response time of the Au/SS wire-based electrochemical microsensor to the $\mathrm{H}_{2} \mathrm{O}_{2}$. Amperometric response to continuous additions of $10 \mu \mathrm{L} \mathrm{H}_{2} \mathrm{O}_{2}$ with concentration $500 \mathrm{mM}$ in $10 \mathrm{~mL}$ solution with $0.2 \mathrm{M}$ PBS ( $\mathrm{pH}$ 7) at $-0.6 \mathrm{~V}$ application potential. (B) The ant-interference ability of the SS wire-based electrochemical microsensor for detection of $\mathrm{H}_{2} \mathrm{O}_{2}$. Amperometric response to continuous additions of $10 \mu \mathrm{L} \mathrm{H}_{2} \mathrm{O}_{2}$, salicylic acid (SA), indole-3-acetic acid (IAA), methyl jasmonate (MeJA), abscisic acid (ABA), ascorbic acid (AA), malic acid $\left(\mathrm{H}_{2} \mathrm{MA}\right)$, succinic acid, and citric acid (CA), and $\mathrm{H}_{2} \mathrm{O}_{2}$ with concentration $100 \mathrm{mM}$, respectively, in $10 \mathrm{~mL}$ solution with $0.2 \mathrm{M}$ PBS (pH 7) at $-0.6 \mathrm{~V}$ application potential.

\subsection{In Vivo and Continuous Electrochemical Monitoring of $\mathrm{H}_{2} \mathrm{O}_{2}$ in Vein of Tomato Leaf}

To study the production of $\mathrm{H}_{2} \mathrm{O}_{2}$ in the veins of the tomato leaf under high salinity stress, $\mathrm{H}_{2} \mathrm{O}_{2}$ was continuously monitored in vivo and based on the Au/SS wire-based electrochemical microsensor. As shown in Figure 6A, the working electrode, counter electrode, and reference electrode of the Au/SS wire-based electrochemical microsensor were placed into the vein of the tomato leaf, followed by transferring $5 \mu \mathrm{L} 0.2 \mathrm{M}$ PBS (pH 7) on the surface of electrodes for electrochemical detection. The typical amperometric $\mathrm{i}-\mathrm{t}$ detection curves of $\mathrm{H}_{2} \mathrm{O}_{2}$ in the vein of tomato with or without high salinity stress for $2 \mathrm{~h}$ are shown in Figure 6B. The results showed that the records of control remained flat during the continuous measurement which suggested a stable $\mathrm{H}_{2} \mathrm{O}_{2}$ concentration in the vein of tomato leaf. With the high salinity stress, $\mathrm{H}_{2} \mathrm{O}_{2}$ was observed to increase about $40 \mathrm{~min}$ and resulted in a large peak at $60 \mathrm{~min}$ (Figure 6B). Figure 6C illustrates the dynamic change in $\mathrm{H}_{2} \mathrm{O}_{2}$ in the vein of tomato leaf from 6.7 to $678.6 \mu \mathrm{M}$. In vivo $\mathrm{H}_{2} \mathrm{O}_{2}$ monitoring with high salinity stress was repeated three times and each experiment yielded similar results of excess $\mathrm{H}_{2} \mathrm{O}_{2}$ accumulation (Figure S5). Respiratory burst oxidase homologs (Rbohs) also known as NADPH oxidases, are key enzymes that can catalyze the generation of ROS in plants [41]. Rbohs-generated ROS has been shown to regulate responses to many abiotic stresses such as drought, heat, cold, and salinity $[42,43]$. Stresses are shown to alter the levels of different plant hormones that in turn regulate RBOHs activity and ROS production via many different mechanisms [43]. Eight SlRboh genes (SlRbohA SlRbohH) were identified in tomato [44]. Among them, $S L R b o h B$ has been proven to positively regulate resistance to $B$. cinerea and drought stress tolerance in tomato [44]. Therefore, the expression analysis of $S l R b o h A$ and $S l R b o h B$ in our studies was performed to confirm our detection results. Comparing the control treatments, the expression levels of SlRbohA and SlRbohB in the veins of tomato leaves under high salinity treatment showed a $>8$-fold increase at $1 \mathrm{~h}$ post treatment, which related to the increase in $\mathrm{H}_{2} \mathrm{O}_{2}$ in the vein of tomato under high salinity stress (Figure 6D). These results suggested that our approach might provide an effective way for in vivo and continuous detection of $\mathrm{H}_{2} \mathrm{O}_{2}$ in plants. 

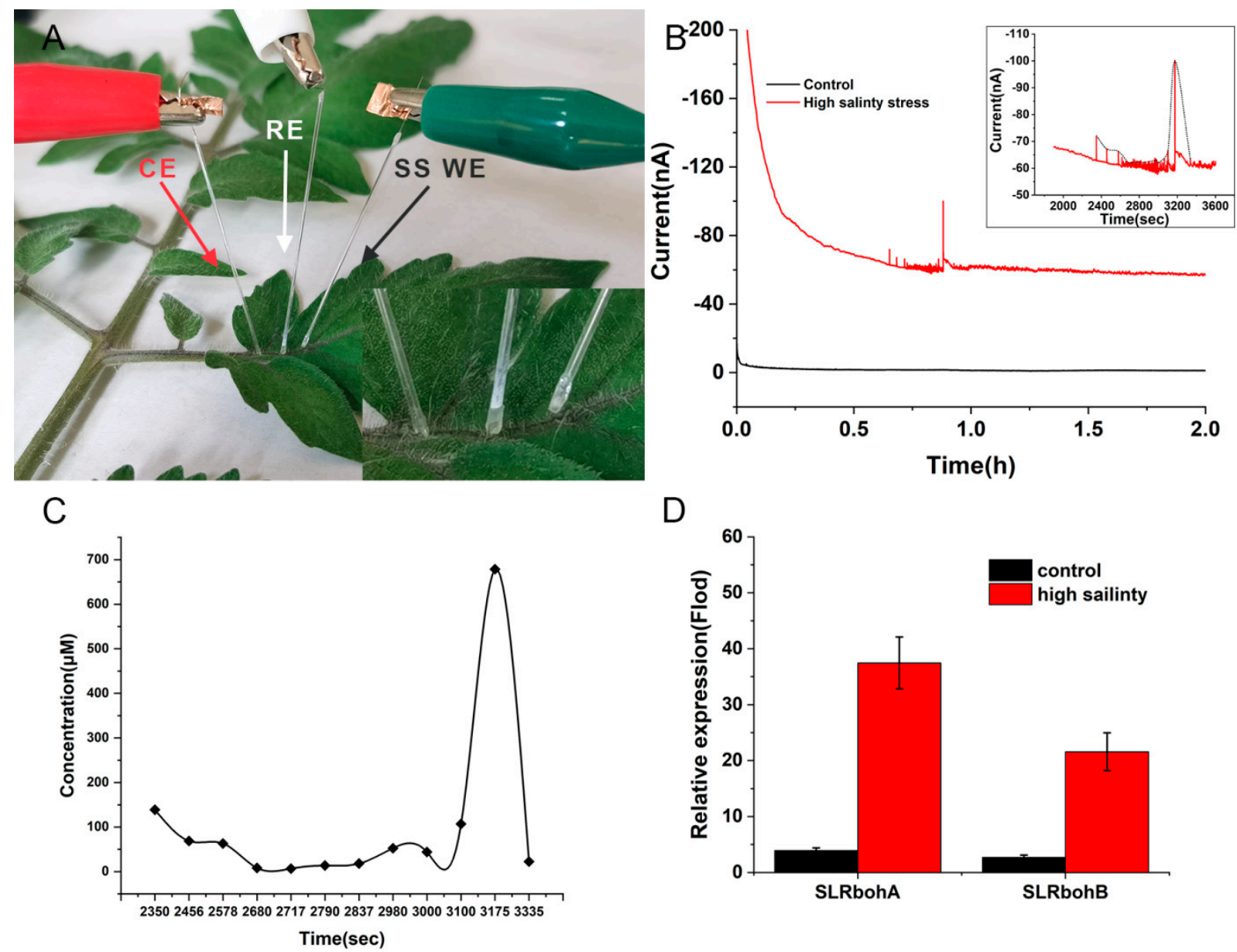

Figure 6. (A) In vivo and continuous electrochemical monitoring of $\mathrm{H}_{2} \mathrm{O}_{2}$ in vein of the tomato leave based on the $\mathrm{Au} / \mathrm{SS}$ wire-based electrochemical microsensor, and the inset showed the enlarged part of the analysis area. (B) The typical amperometric i-t detection curve of $\mathrm{H}_{2} \mathrm{O}_{2}$ in vein of the tomato leaves under the high salinity stress, and the inset showed the enlarged part of $\mathrm{H}_{2} \mathrm{O}_{2}$ from 40 to 60 min. (C) illustrated the dynamic change in $\mathrm{H}_{2} \mathrm{O}_{2}$ in vein of tomato leaf. (C) The dynamic change in $\mathrm{H}_{2} \mathrm{O}_{2}$ in vein of tomato leaf under the high salinity stress. (D)The expression level of SLRbohA and $S L R b o h B$ under the high salinity stress.

\section{Conclusions}

In this study, we developed a disposable Au/SS wire-based electrochemical microsensor to detect $\mathrm{H}_{2} \mathrm{O}_{2}$ in vivo and continuously. Compared to the traditional methods, the complicated and time-consuming treatment processing for quantification of $\mathrm{H}_{2} \mathrm{O}_{2}$ in the plant samples was avoided, which could ensure continuously obtaining the $\mathrm{H}_{2} \mathrm{O}_{2}$ concentration in vivo. With our approach, the dynamic change in $\mathrm{H}_{2} \mathrm{O}_{2}$ in the vein of tomato leaf under high salinity was continuously monitored in vivo. Our strategy will help to pave the foundation for further investigation of the generation, transportation, and elimination mechanisms of $\mathrm{H}_{2} \mathrm{O}_{2}$ in plants.

Supplementary Materials: The following are available online at https: / www.mdpi.com/article/ 10.3390/bios12010035/s1, Table S1: The qRT-PCR primers; Table S2: List of analytical performance of electrochemical methods for detection of $\mathrm{H}_{2} \mathrm{O}_{2}$ in the plants; Figure S1: The method of high salinity stress for the tomato; Figure S2: (A) Pt electrode was used as counter electrode and $\mathrm{Ag} / \mathrm{AgCl}$ electrode as reference electrode. (B) SS electrodes were used as counter electrode and reference electrode. The Amperometric response of the Au/SS wire-based electrochemical microsensor to successive additions of $10 \mu \mathrm{L} \mathrm{H}_{2} \mathrm{O}_{2}$ with concentration $100 \mathrm{mM}$ in $10 \mathrm{~mL}$ solution with $0.2 \mathrm{M}$ PBS ( $\mathrm{pH} 7)$ at $-0.6 \mathrm{~V}$ application potential; Figure S3: (A) The Amperometric response of the Au/SS wire 
with the different diameter based electrochemical microsensor to successive additions of $10 \mu \mathrm{L} \mathrm{H}_{2} \mathrm{O}_{2}$ with concentration $100 \mathrm{mM}$ in $10 \mathrm{~mL}$ solution with $0.2 \mathrm{M} \mathrm{PBS}(\mathrm{pH} 7)$ at $-0.6 \mathrm{~V}$ application potential. (B) The relationship between the amperometric response and the diameter of SS $(n=5)$; Figure S4: (A) One Au/SS wire-based electrochemical microsensor was repeated for 7 times.(B) Seven Au/SS wire-based electrochemical microsensors were fabricated at the same time and then were tested at following seven days. Amperometric response of the Au/SS wire-based electrochemical microsensor to successive additions of $10 \mu \mathrm{L} \mathrm{H}_{2} \mathrm{O}_{2}$ with concentration $100 \mathrm{mM}$ in $10 \mathrm{~mL}$ solution with $0.2 \mathrm{M}$ PBS $(\mathrm{pH} 7)$ at $-0.6 \mathrm{~V}$ application potential; Figure S5: The in vivo $\mathrm{H}_{2} \mathrm{O}_{2}$ monitoring in vein of tomato with high salinity stress.

Author Contributions: Conceptualization, L.S.; methodology and investigation, D.H., D.L. (Daodong Li) and S.X.; validation, Y.T. and X.X.; data curation, D.H., D.L. (Daodong Li) and S.X.; writingoriginal draft preparation, Y.Z., A.L. and L.S.; writing-review and editing, D.L. (Dayong Li), F.S., Y.Z., A.L. and L.S.; supervision and project administration, L.S. All authors have read and agreed to the published version of the manuscript.

Funding: This work was supported by the National Natural Science Foundation of China (Nos: 31770399 and 21974012), the Natural Science Foundation of Jiangsu Province (Nos: BK20130389), the project of Nantong Natural Science Foundation (MS22021038 and MS12021012), Qing Lan Project of Jiangsu Province, Six talent peaks project in Jiangsu Province (No: SWYY-061), and the science and technology innovation project of Jiangsu Province (202110304080Y).

Institutional Review Board Statement: Not applicable.

Informed Consent Statement: Not applicable.

Data Availability Statement: Not applicable.

Conflicts of Interest: The authors declare no conflict of interest.

\section{References}

1. Černý, M.; Habánová, H.; Berka, M.; Luklová, M.; Brzobohatý, B. Hydrogen peroxide: Its role in plant biology and crosstalk with signalling networks. Int. J. Mol. Sci. 2018, 19, 2812. [CrossRef] [PubMed]

2. Das, K.; Roychoudhury, A. Reactive oxygen species (ROS) and response of antioxidants as ROS-scavengers during environmental stress in plants. Front. Environ. Sci. 2014, 2, 53. [CrossRef]

3. Dietz, K.J.; Turkan, I.; Krieger-Liszkay, A. Redox- and reactive oxygen species-dependent signaling into and out of the photosynthesizing chloroplast. Plant Physiol 2016, 171, 1541-1550. [CrossRef] [PubMed]

4. Huang, S.; Van-Aken, O.; Schwarzländer, M.; Belt, K.; Millar, A.H. The roles of mitochondrial reactive oxygen species in cellular signaling and stress response in plants. Plant Physiol 2016, 171, 1551-1559. [CrossRef] [PubMed]

5. Khorobrykh, S.A.; Karonen, M.; Tyystjärvi, E. Experimental evidence suggesting that $\mathrm{H}_{2} \mathrm{O}_{2}$ is produced within the thylakoid membrane in a reaction between plastoquinol and singlet oxygen. FEBS Lett. 2015, 589, 779-786. [CrossRef] [PubMed]

6. Wrzaczek, M.; Brosché, M.; Kangasjärvi, J. Ros signalling loops -production, perception, regulation. Curr. Opin. Plant. Biol. 2013, 16, 575-582. [CrossRef]

7. Cheeseman, J.M. Hydrogen peroxide concentrations in leaves under natural conditions. J. Exp. Bot. 2006, 57, 2435-2444. [CrossRef]

8. Chaparzadeh, N.; D’Amico, M.L.; Khavari-Nejad, R.A.; Izzo, R.; Navari-Izzo, F. Antioxidative responses of calendula officinalis under salinity conditions. Plant Physiol Biochem. 2004, 42, 695-701. [CrossRef]

9. Chen, Z.; Silva, H.; Klessig, D. Active oxygen species in the induction of plant systemic acquired resistance induced by salicylic acid. Science 1993, 262, 1883-1886. [CrossRef]

10. Tewari, R.K.; Singh, P.K.; Watanabe, M. The spatial patterns of oxidative stress indicators co-locate with early signs of natural senescence in maize leaves. Acta. Physiol Plant 2013, 35, 949-957. [CrossRef]

11. Gill, S.S.; Tuteja, N. Reactive oxygen species and antioxidant machinery in abiotic stress ktolerance in crop plants. Plant Physiol Biochem. 2010, 48, 909. [CrossRef]

12. Saxena, I.; Srikanth, S.; Chen, Z. Cross talk between $\mathrm{H}_{2} \mathrm{O}_{2}$ and interacting signal molecules under plant stress response. Front. Plant Sci. 2016, 7, 570. [CrossRef]

13. Pei, Z.M.; Murata, Y.; Benning, G.; Thomine, S.; Klüsener, B.; Allen, G.J.; Grill, E.; Schroeder, J.I. Calcium channels activated by hydrogen peroxide mediate abscisic acid signalling in guard cells. Nature 2000, 406, 731-734. [CrossRef]

14. Chen, Z.; Klessig, D.F. Identification of a soluble salicylic acid-binding protein that may function in signal transduction in the plant disease-resistance response. Proc. Natl. Acad. Sci. USA 1991, 88, 8179-8183. [CrossRef]

15. Levine, A.; Tenhaken, R.; Dixon, $\mathrm{R} . \mathrm{H}_{2} \mathrm{O}_{2}$ from the oxidative burst orchestrates the plant hypersenesitive disease resistance response. Cell 1994, 79, 583-593. [CrossRef] 
16. Elnemma, E.M. Spectrophotometric determination of hydrogen peroxide by a hydroquinone-aniline system catalyzed by molybdate. Bull. Korean. Chem. Soc. 2004, 25, 127-129.

17. Klassen, N.V.; Marchington, D.; McGowan, H.C.E. $\mathrm{H}_{2} \mathrm{O}_{2}$ determination by the I3- method and by $\mathrm{KMnO}_{4}$ titration. Anal. Chem 1994, 66, 2921-2925. [CrossRef]

18. Pick, E.; Keisari, Y. A simple colorimetric method for the measurement of hydrogen peroxide produced by cells in culture. J. Immunol. Methods 1980, 38, 161-170. [CrossRef]

19. Segawa, T.; Kamidate, T.; Watanabe, H. Determination of hydrogen peroxide with fluorescein chemiluminescence catalyzed by horseradish peroxidase. Anal. Sci. 1990, 6, 763-764. [CrossRef]

20. Takahashi, A.; Hashimoto, K.; Kumazawa, S.; Nakayama, T. Deter- mination of hydrogen peroxide by high-performance liquid chromatography with a cation-exchange resin gel column and electrochemical detector. Anal. Sci. 1999, 15, 481-483. [CrossRef]

21. Cheng, D.; Qin, J.; Feng, Y.; Wei, J. Synthesis of mesoporous cuo hollow sphere nanozyme for paper-based hydrogen peroxide sensor. Biosensors 2021, 11, 258. [CrossRef]

22. Rezvani, E.; Hatamie, A.; Berahman, M.; Simchi, M.; Angizi, S.; Rahmati, R.; Kennedy, J.; Simchi, A. Synthesis, first-principle simulation, and application of three-dimensional ceria nanoparticles/graphene nanocomposite for non-enzymatic hydrogen peroxide detection. J. Electrochem. Soc. 2019, 166, H3167-H3174. [CrossRef]

23. Patel, V.; Kruse, P.; Selvaganapathy, P.R. Solid state sensors for hydrogen peroxide detection. Biosensors 2021, 11, 9. [CrossRef]

24. Pundir, C.S.; Deswal, R.; Narwal, V. Quantitative analysis of hydrogen peroxide with special emphasis on biosensors. Bioprocess. Biosyst. Eng. 2018, 41, 313-329. [CrossRef]

25. Sun, L.J.; Xie, Y.; Yan, Y.F.; Yang, H.; Gu, H.Y.; Bao, N. Paper-based analytical devices for direct electrochemical detection of free IAA and SA in plant samples with the weight of several milligrams. Sens. Actuators B Chem. 2017, 247, 336-342. [CrossRef]

26. Sun, L.J.; Feng, Q.M.; Yan, Y.; Pan, Z.Q.; Li, X.H.; Song, F.M.; Yang, H.; Xu, J.J.; Bao, N.; Gu, H.Y. Paper-based electroanalytical devices for in situ determination of salicylic acid in living tomato leaves. Biosens. Bioelectron. 2014, 60, 154-156. [CrossRef] [PubMed]

27. Diacci, C.; Abedi, T.; Lee, J.W.; Gabrielsson, E.O.; Berggren, M.; Simon, D.; Niittylä, T.; Stavrinidou, E. Diurnal in vivo xylem sap glucose and sucrose monitoring using implantable organic electrochemical transistor sensors. Iscience 2020, 24, 101966. [CrossRef]

28. Ai, F.; Chen, H.; Zhang, S.H.; Liu, S.Y.; Wei, F.; Dong, X.Y.; Cheng, J.K.; Huang, W.H. Real-time monitoring of oxidative burst from single plant protoplasts using microelectrochemical sensors modified by platinum nanoparticles. Anal. Chem. 2009, 81, 8453-8458. [CrossRef]

29. Lima, A.S.; Prieto, K.R.; Santos, C.S.; Valerio, H.P.; Garcia-Ochoa, E.Y.; Huerta-Robles, A.; Beltran-Garcia, M.J.; Di Mascio, P.; Bertotti, M. In-vivo electrochemical monitoring of $\mathrm{H}_{2} \mathrm{O}_{2}$ production induced by root-inoculated endophytic bacteria in Agave tequilana leaves. Biosens. Bioelectron. 2018, 99, 108-114. [CrossRef] [PubMed]

30. Ren, Q.Q.; Yuan, X.J.; Huang, X.R.; Wen, W.; Zhao, Y.D.; Chen, W. In vivo monitoring of oxidative burst on aloe under salinity stress using hemoglobin and single-walled carbon nanotubes modified carbon fiber ultra microelectrode. Biosens. Bioelectron. 2013, 50, 318-324. [CrossRef]

31. Sun, L.J.; Pan, Y.; Wu, J.; Zhao, D.Y.; Hui, M.Q.; Zhu, S.Q.; Zhu, X.Y.; Li, D.Y.; Song, F.M.; Zhang, C.K. Paper-Based Analytical Devices for the Rapid and Direct Electrochemical Detection of Hydrogen Peroxide in Tomato Leaves Inoculated with Botrytis cinerea. Sensors 2020, 20, 5512. [CrossRef]

32. Rezaei, B.; Havakeshian, E.; Ensafi, A.A. Decoration of nanoporous stainless steel with nanostructured gold via galvanicreplacement reaction and its application for electrochemical determination of dopamine. Sens. Actuators B Chem. 2015, 213, 484-492. [CrossRef]

33. Rezaei, B.; Shams-Ghahfarokhi, L.; Havakeshian, E.; Ensafi, A.A. An electrochemical biosensor based on nanoporous stainless steelmodified by gold and palladium nanoparticles for simultaneous determination of levodopa and uric acid. Talanta 2016, 158, 42-50. [CrossRef] [PubMed]

34. Kitte, S.A.; Li, S.; Nsabimana, A.; Gao, W.Y.; Lai, J.P.; Liu, Z.Y.; Xu, G.B. Stainless steel electrode for simultaneous stripping analysis of $\mathrm{Cd}(\mathrm{II}), \mathrm{Pb}(\mathrm{II}), \mathrm{Cu}(\mathrm{II})$ and $\mathrm{Hg}(\mathrm{II})$. Talanta 2019, 191, 485-490. [CrossRef] [PubMed]

35. Lo, K.H.; Shek, C.H.; Lai, J. Recent developments in stainless steels. Mater. Sci. Eng. R Rep. 2009, 65, 39-104. [CrossRef]

36. Latif, T.; McKnight, M.; Dickey, M.D.; Bozkurt, A. In vitroelectrochemical assessment of electrodes for neurostimulation in roach biobots. PLoS ONE 2018, 13, e0203880. [CrossRef]

37. Livak, K.J.; Schmittgen, T.D. Analysis of relative gene expression data using real-time quantitative PCR and the $2^{-\Delta \Delta C_{T}}$ method. Methods 2001, 25, 402-408. [CrossRef]

38. Cao, S.; Yuan, R.; Chai, Y.; Zhang, L.; Li, X.; Gao, F. A mediator-free amperometric hydrogen peroxide biosensor based on HRP immobilized on a nano-Au/poly 2,6-pyridinediamine-coated electrode. Bioprocess. Biosyst. Eng. 2007, 30, 71-78. [CrossRef]

39. Castro-Mercado, E.; Martinez-Diaz, Y.; Roman-Tehandon, N.; Garcia-Pineda, E. Analysis of reactive oxygen species production and antioxidative responses in unripe avocado (Persea americana Mill var Hass) fruits in response to wounding. Protoplasma 2009, 235, 67-76. [CrossRef]

40. Wang, J.; Wang, L.; Di, J.; Tu, Y. Electrodeposition of gold nanoparticles on indium/tin oxide electrode for fabrication of a disposable hydrogen peroxide biosensor. Talanta 2009, 77, 1454-1459. [CrossRef]

41. Suzuki, N.; Miller, G.; Morales, J.; Shulaev, V.; Torres, M.A.; Mittler, R. Respiratory burst oxidases: The engines of ROS signaling. Curr. Opin. Plant Biol. 2011, 14, 691-699. [CrossRef] [PubMed] 
42. Baxter, A.; Mittler, R.; Suzuki, N. ROS as key players in plant stress signaling. J. Exp. Bot. 2014, 65, 1229-1240. [CrossRef]

43. Devireddy, A.R.; Zandalinas, S.I.; Fichman, Y.; Mittler, R. Integration of reactive oxygen species and hormone signaling during abiotic stress. Plant J. 2021, 105, 459-476. [CrossRef] [PubMed]

44. Li, X.H.; Zhang, H.J.; Tian, L.M.; Huang, L.; Liu, S.X.; Li, D.Y.; Song, F.M. Tomato SIRbohB, a member of the NADPH oxidase family, is required for disease resistance against Botrytis cinerea and tolerance to drought stress. Front. Plant Sci. $2015,6,463$. [CrossRef] [PubMed] 